J. Japan. Soc. Hort. Sci. 50(3) : 379-385. 1981.

\title{
The Increase in Activities of Acid Phosphatase and Ribonuclease during Ripening of Banana Fruit
}

\author{
Hiroshi Hyodo, Kuniaki Tanaka, Toshiro Suzuki, \\ Masayuki Mrzukoshi and Yoshifumi Tasaka \\ Department of Horticulture, Faculty of Agriculture, \\ Shizuoka University, Ohya, Shizuoka 422
}

\begin{abstract}
Summary
Both acid phosphatase and ribonuclease activities increased markedly in close relation with the climacteric and the subsequent senescence in the pulp tissue of banana (Musa AAA group, Cavendish subgroup cv. Giant Cavendish). fruit The activity of acid phosphatase increased in both supernatant and precipitate obtained by centrifugation at low speed, e.g. $2,000 \times g$. At an earlier stage of ripening, however, the activity in the precipitate was much higher than that in the supernatant fraction. In the case of ribonuclease, the greater activity was found in the supernatant fraction throughout the period of ripening. Polyacrylamide gel electrophoresis separated acid phosphatase into 9 bands. There were essentially no qualitative differences in isozymes between supernatant and precipitate fractions, nor between unripe and ripe fruis, although some isozymes appeared to increase in activity during ripening. There was a gradual decline in the rate of ${ }^{14} \mathrm{C}$-leucine incorporation into protein of the pulp tissue of banana fruit during ripening, while there was a sharp increase in ribonuclease and acid phosphatase activities.
\end{abstract}

\section{Introduction}

Fruit ripening involves a rise in respiration (the respiration climacteric), increase in membrane permeability, softening, starch breakdown to soluble sugars, destruction of chlorophyll, production of pigments, and formation of flavor and aroma. These phenomena of senescence are induced or accelerated by ethylene. In addition to the above features, it is known that several enzymes are induced or increased in activity following the ripening of fruit $(12,14)$.

Banana is one of the fruits that manifest a typical climacteric and the associated features of ripening. Ripening is induced by the application of ethylene and sustained by subsequent maintenance at moderate temperature and by high relative humidity. De Leo and Sacher (5) demonstrated that acid phosphatase

Received for publication June 11, 1981, This work was supported in part by the Agricultural Chemical Research Foundation.
(APase) activity rose markedly during the ripening of banana fruit and that the greater activity was associated with the heavy fraction precipitated at $500 \times g$. They also suggested that the increased activity of APase during ripening was due to new enzyme synthesis, rather than enzyme activation. Yoshioka et al. (19) reported that the increase in APase activity was inhibited by maintaining fruit at $40^{\circ} \mathrm{C}$, a temperature at which normal ripening of banana was arrested. They suggested that protein synthesis activity was repressed at 40 ${ }^{\circ} \mathrm{C}$, which led to the inhibition of development of APase (20).

In the present paper we report that ribonuclease (RNase) activity, as well as APase activity, increases remarkably during ripening of the banana. Localization of both of these enzymes in subcellular fractions, changes in electrophoretic patterns of APase, and change in the rate of amino acid incorporation into protein during fruit ripening are also shown. The meaning of the rise in the activities of these enzymes will be discussed in relation to 
fruit ripening and senescence.

\section{Materials and Methods}

\section{Materials}

Hands of green bananas (Musa AAA group, Cavendish subgroup cv. Giant Cavendish) (17) or bananas gassed by application of about $300 \mu l / l$ ethylene for one day at $20^{\circ} \mathrm{C}$, were obtained from Matsui Fruit Co., Shizuoka. They were allowed to ripen at $25^{\circ} \mathrm{C}$ and high relative humidity (about $90 \% \mathrm{RH}$ ) in a flowing stream of humidified air.

Measurements of ethylene production and respiration

Bananas were placed in a sealed chamber for 2 to $3 \mathrm{hr}$ and $11 \mathrm{ml}$ gas samples of the atmosphere were withdrawn through a silicone rubber stopper by a hypodermic syringe. Ethylene concentrations were determined by flame ionization gas chromatography with an activated alumina column. $\mathrm{CO}_{2}$ concentrations were determined by thermal conductivity gas chromatography, using a Porapak R column.

\section{Color score}

Ripening was assessed by scoring changes in peel color. The scoring system (rating scale) for ripening based on peel color, brown spotting and flesh firmness was : $1=$ all green; $2=$ light green ; $3=$ half green ; $4=$ half yellow; $5=$ green tip $; 6=$ full yellow $; 7=$ brown spot ting ; $8=$ overripe.

\section{Enzyme extraction}

At appropriate intervals during the course of ripening, fruit pulp was sampled and extracted for APase and RNase. Cross-sectional slices were weighed after removal of peel. Pulp (4 to $5 \mathrm{~g}$ ) was ground in $30 \mathrm{ml}$ of 0.02 $\mathrm{M}$ sodium-acetate buffer, $\mathrm{pH} 5.5$, containing $10 \mathrm{mM}$ 2-mercaptoethanol (medium A) with a mortar and pestle in ice bath. The homogenate was centrifuged at $2,000 \times g$ for $20 \mathrm{~min}$ at $2^{\circ} \mathrm{C}$. The supernatant $\left(\mathrm{S}_{1}\right)$ was decanted and the precipitate transferred to a mortar and further ground in $20 \mathrm{ml}$ of medium A plus $1 \%$ Triton $\mathrm{X}-100$ (medium B). This preparation was then centrifuged at $2,000 \times g$ for $20 \mathrm{~min}$. The supernatant $\left(\mathrm{S}_{2}\right)$ was decanted and saved. APase and PNase activities were found in both $S_{1}$ and $S_{2}$, but in different proportions for each enzyme and for different stages of ripening. In some experiments pulp tissue was extracted directly with medium B for assay of total activities of both enzymes. Assay of APase and RNase

For assaying APase, $0.2 \mathrm{ml}$ of enzyme preparation were added to $0.6 \mathrm{ml}$ of $0.2 \mathrm{M}$ sodium-acetate buffer, pH 5.5, and $0.2 \mathrm{ml}$ of $0.02 \mathrm{M} p$-nitrophenylphosphate in a test tube. The mixture was incubated at $37^{\circ} \mathrm{C}$ for $15 \mathrm{~min}$ and then $3 \mathrm{~m} l$ of $0.167 \mathrm{~N} \mathrm{NaOH}$ were added. The absorbance was measured at $400 \mathrm{~nm}$ to determine the $p$-nitrophenol liberated in the reaction. A unit of enzyme activity was defined as that amount of enzyme which produced an increase in absorbance at $400 \mathrm{~nm}$ of 1.0 per $15 \mathrm{~min}$. RNase was assayed according to the method described by Sacher et al. (16). The reaction mixture included $0.5 \mathrm{ml}$ of $0.2 \mathrm{M}$ PIPES (piperazine-N, $\mathrm{N}^{\prime}$-bis [2ethanesulfonic] acid) buffer, $\mathrm{pH} 6.5,0.2 \mathrm{~m} l$ of $1 \%$ yeast RNA and $0.3 \mathrm{~m} l$ of enzyme; and was incubated at $37^{\circ} \mathrm{C}$ for $2 \mathrm{hr}$ in a test tube. The reaction was stopped by addition of $5 \mathrm{ml}$ of $95 \%$ ethanol. After chilling in a freezer $\left(-15^{\circ} \mathrm{C}\right)$ overnight, the mixture was centrifuged at $14,000 \times g$ for $20 \mathrm{~min}$ and the absorbance of the ethanol-soluble fraction of nucleotides was measured at $260 \mathrm{~nm}$ against a zerotime blank. A unit of enzyme activity was defined as that amount of enzyme which produced an increase in absorbance at $260 \mathrm{~nm}$ of 1.0 per $2 \mathrm{hr}$.

Polyacrylamide gel electrophoresis

Electrophoresis of APase was carried out in a vertical $2-\mathrm{mm}$-thick slab of polyacrylamide gel. The gel consisted of $7.3 \%$ acrylamide buffered with Tris- $\mathrm{HCl}, \mathrm{pH}$ 8.9. Aliquots (50 $\mu l$ ) of the enzyme extracts in $0.3 \mathrm{M}$ sucrose were placed in the sample slots. The electrode vessels contained Tris-glycine buffer, $\mathrm{pH}$ 8.3, and electrophoresis was performed at $15 \mathrm{v} / \mathrm{cm}$ for 5 to $6 \mathrm{hr}$ in a cold room. The final locations of the APases were revealed by staining the gel at $30^{\circ} \mathrm{C}$ for $2 \mathrm{hr}$ with a solution made up of equal volumes of $0.02 \% \quad \alpha$-naphthylphosphate and $0.02 \%$ Fast Garnet GBC Salt (o-amino azotoluene diazonium salt) in $0.5 \mathrm{M}$ sodium-acetate buffer, pH 5.5 (18).

Amino acid incorporation into protein

Banana fruit was surface-sterilized in $0.5 \%$ 
$(\mathrm{w} / \mathrm{v})$ sodium hypochlorite solution for $10 \mathrm{~min}$. Duplicate 5 -mm-thick cross sections were cut from the central zone. Each slice was placed in $6 \mathrm{ml}$ of $0.1 \mathrm{M} \mathrm{KCl}$ solution containing 1.5 $\mu \mathrm{Ci} \mathrm{L}-\left[\mathrm{U}-{ }^{14} \mathrm{C}\right]$ leucine $(342 \mathrm{mCi} / \mathrm{mmol})$ and $0.3 \mathrm{mg}$ chloramphenicol, followed by vacuum infiltration at about $400 \mathrm{~mm}-\mathrm{Hg}$ for $1 \mathrm{~min}$. The infiltrated slices were quickly blotted with filter paper and incubated at $25^{\circ} \mathrm{C}$ for $1 \mathrm{hr}$. After incubation peel was removed and the slice was placed in $50 \mathrm{~m} l$ of $90 \%$ ethanol, boiled for $30 \mathrm{~min}$, and then ground with a mortar and pestle. The homogenate was centrifuged at $7,000 \times g$ for $20 \mathrm{~min}$ at $2^{\circ} \mathrm{C}$. The supernatant fraction was removed, and the precipitate twice washed with $80 \%$ ethanol. The precipitate was then ground in $20 \mathrm{~m} l$ of $2 \%$ SDS solution with a mortar and pestle, and the homogenate centrifuged at $7,000 \times g$ for $20 \mathrm{~min}$. The precipitate was again ground in $20 \mathrm{~m} l$ of $2 \%$ SDS and centrifuged. Finally the precipitate was washed with $5 \mathrm{ml}$ of $2 \%$ SDS, centrifuged and the washing was combined with the above two SDS supernatants. An aliquot of this solution $(0.5 \mathrm{~m} l)$ was mixed with $5 \mathrm{ml}$ of scintillation fluid and the radioactivity determined in a liquid scintillation spectrometer. Radioactivity was expressed as $\mathrm{dpm}$ after quenching and efficiency corrections. Protein content was determined by the method of Lowry et al. (7) using bovine serum albumin as a standard.

Chemicals

$p$-Nitrophenylphosphte disodium salt was obtained from Wako. RNA from P-L Biochemicals, $\alpha$-naphthylphosphate disodium salt and Fast Garnet GBC salt from Sigma, and $\mathrm{L}-\left[\mathrm{U}-{ }^{14} \mathrm{C}\right]$ leucine and scintillation solution ('Atomlight') from New England Nuclear. All other chemicals were of reagent grade.

\section{Results}

The $\mathrm{pH}$ optima for APase and RNase activities were 5.5 and 6.5 , respectively (Fig. 1). Both APase and RNase activities increased markedly as ripening progressed. In banana fruit the respiration climacteric is known to be initiated by ethylene (4). It is shown in Fig. 2 that the rise in respiration paralleled ethylene production. After reaching a maxi-

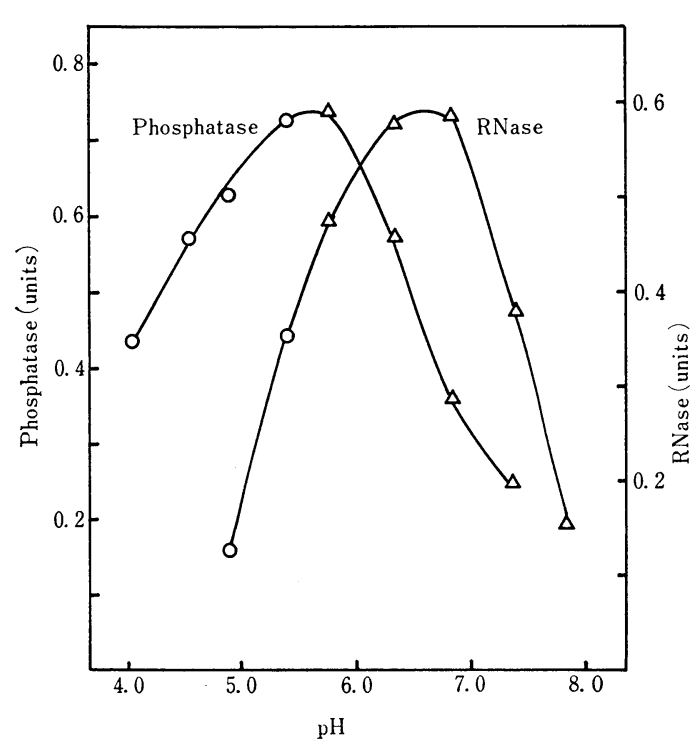

Fig.1. The effect of $\mathrm{pH}$ on the activities of APase and RNase extracted from banana pulp tissue. Two buffer systems were used for the range of pH tested, i. e., sodium-acetate buffer $(O)$ and PIPES buffer $(\triangle)$.

mum on day 10 from the beginning of experiment, both ethylene production and the respiration rate declined to a minimum, followed by a small rise. Both APase and RNase began to increase in activity with the rise in ethylene production and respiration. They continued to increase over the entire period of the ripening process until about day 16, when the flesh became very soft and the peel was covered with dark-brown blots. APase activity increased both in the $2,000 \times g$-supernatant fraction (sup) and in the $2,000 \times g$-precipitate (ppt) (Fig. 3). In the case of RNase, the activity occurred predominantly in the supernatant fraction throughout ripening. The marked increases in APase and RNase activities were also shown during the ripening triggered by ethylene (Fig.4). Fruits were exposed to ethylene at $20^{\circ} \mathrm{C}$ for 1 day, and then kept at $25^{\circ} \mathrm{C}$ under a stream of humidified air. Ethylene production by the treated fruit increased to a maximum on day 6 , and then decreased rapidly. A sharp transient rise in respiration was followed by a decline and a second rise, which reached a maximum concurrent with the peak of ethylene production. Both APase 


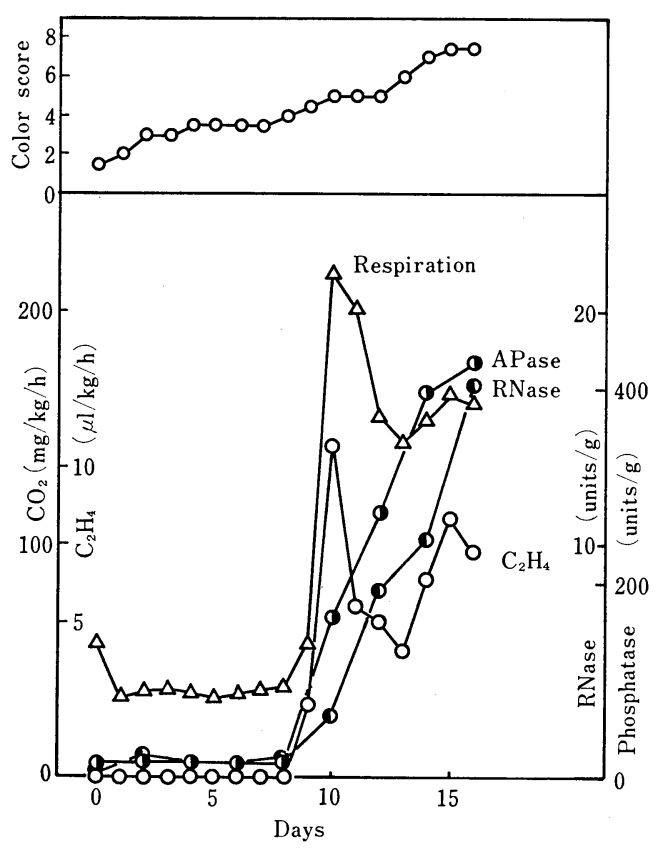

Fig. 2. Increases in color score, ethylene production, respiration $\left(\mathrm{CO}_{2}\right.$ evolution) and total activities of APase and RNase during ripening of banana fruit. Green banana fruits were allowed to ripen naturally at $25^{\circ} \mathrm{C}$ and under high relative humidity. $(\bigcirc)$, ethylene production; $(\triangle)$, respiration ; (○), APase ; (\), RNase. Enzyme activities are expressed as units per $\mathrm{g}$ fresh weight of pulp tissue.

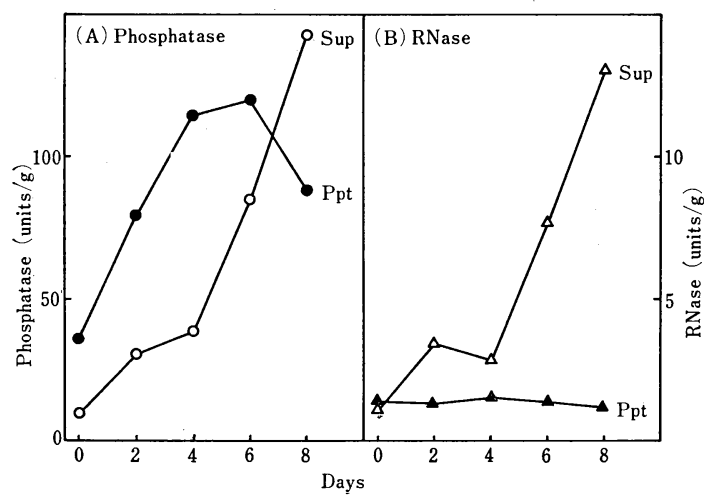

Fig.3. Increases in the activities of APase and RNase in 2,000 $\times g$-supernatant (sup) and $2,000 \times g$ precipitate (ppt) fractions. The precipitate obtained by centrifugation at $2,000 \times g$ was extracted by medium $B$ as described in Materials and Methods. Enzyme activities are expressed as units per $\mathrm{g}$ fresh weight.

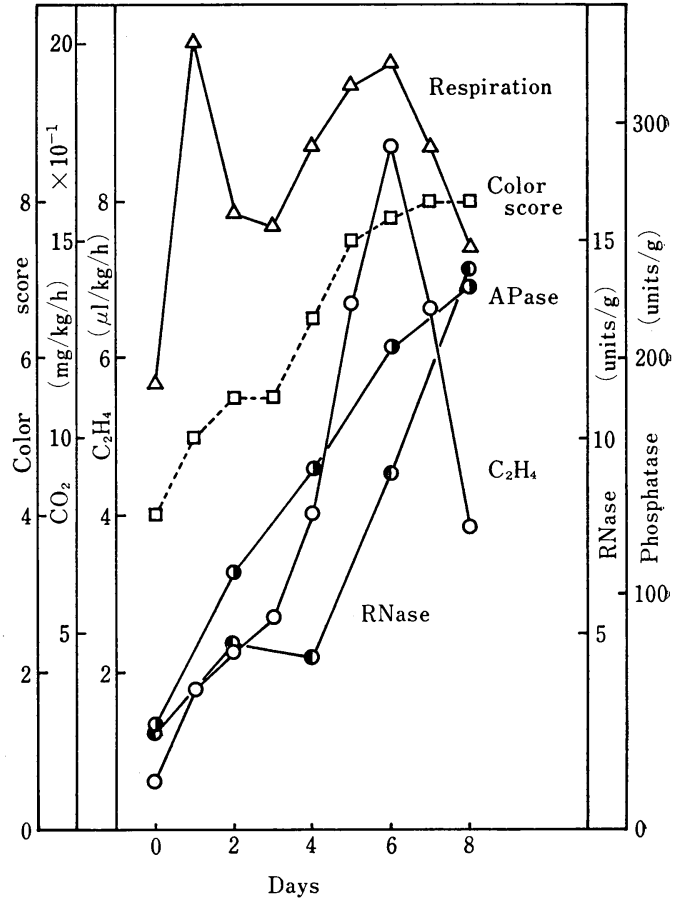

Fig.4. Increases in color score, ethylene production, respiration $\left(\mathrm{CO}_{2}\right.$ evolution) and total activities of APase and RNase during ethylene-induced ripening of banana fruit. Fruits were kept at $25^{\circ} \mathrm{C}$ under a stream of humidified air after treatment with ethylene. (O), ethylene production ; $(\triangle)$, respiration ; $(\square)$, color score ; $(\mathbf{O})$, APase; (\), RNase. Enzyme activities are expressed as units per $\mathrm{g}$ fresh weight of pulp tissue and represent the total of supernatant and precipitate fractions.

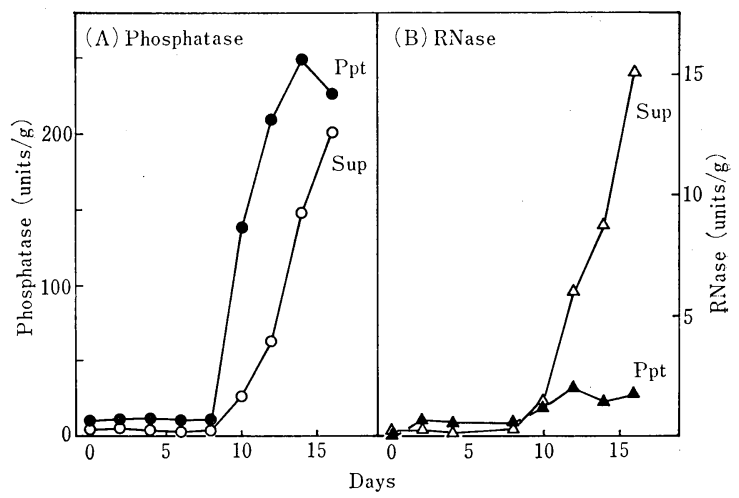

Fig.5. Increases in the activities of APase and RNase in supernatant (sup) and precipitate (ppt) fractions during ethylene-induced ripening of banana fruit. Enzyme activities are expressed as units per $g$ fresh weight. 
and RNase activities greatly increased with the progress of ripenning, and continued to rise until fruit reached complete senescence. During the first 6 days, APase activity was higher in the precipitate fraction than in supernatant fraction (Fig. 5). Later, the higher activity appeared in supernatant fraction. In contrast to APase, RNase activity was found mostly in the supernatant fraction throughout the ripening period.

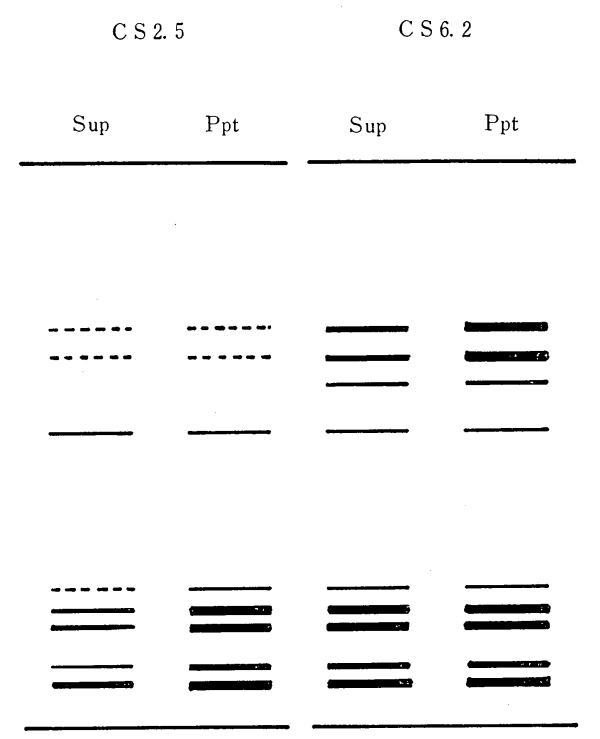

Fig.6. Diagram of electrophoretic patterns of APase on polyacrylamide gel. Fruits were extracted for enzymes at two different stages of ripening and separated into two supernatant and precipitate fractions by centrifugation. Two stages of ripeness, as represented by color score (CS), are shown.
Polyacrylamide gel electrophoresis separated APases of banana fruit into 9 bands (Fig. 6). There were essentially no differences in isozy mes between supernatant and precipitate fractions. The electrophoretic patterns of unripe (color score 2.5) and ripe (color score 6.2) fruits were very similar. Some isozymes appeared to increase in activity during ripening.

Incorporation of ${ }^{14} \mathrm{C}$-leucine into protein decreased during the ripening of banana fruit induced by ethylene (Table 1). The uptake of ${ }^{14} \mathrm{C}$-leucine into the ethanol soluble fraction of the tissue increased, however, as fruit ripening proceeded.

\section{Discussion}

Both APase and RNase activities increased markedly with the progress of ripening of banana fruit. De Leo and Sacher (5) reported that APase activity increased in the 'Gros Michel' or 'Valery' banana fruit during ripening and that a much higher activity existed in the precipitate fraction than in the supernatant fraction. In the present experiments, however, the activity in the supernatant fraction attained a level comparable to that in the precipitate fraction at the stage of senscence. It may be considered that in the later stages of ripening the nature of the cell wall and the plasmalemma are changed, and that the binding of APase to its site of action may be altered accordingly.

Young (21) found that inclusion of $7 \%$ Carbowax 7,000 in the extraction medium prevented nonspecific binding of protein to the cell debris caused by tannins and insured a high activity of aldolase. We have used

Table 1. Incorporation into protein and uptake into $80 \%$ ethanol fraction of $\mathrm{L}-\left[\mathrm{U}-{ }^{14} \mathrm{C}\right]$ leucine and increase in RNase activity of banana fruit during progress of ripening.

\begin{tabular}{c|c|c|c|c}
\hline \hline Day & Color score & $\begin{array}{c}\text { Uptake into 80\% } \\
\text { ethanol fraction } \\
\text { (dpm/g fr wt) }\end{array}$ & $\begin{array}{c}\text { Incorporation } \\
\text { into protein } \\
\text { (dpm/mg protein) }\end{array}$ & $\begin{array}{c}\text { RNase activity } \\
\text { (units/mg protein) }\end{array}$ \\
\hline 0 & 2.4 & $25,491^{*}$ & $1,693^{*}$ & $0.48^{*}$ \\
2 & 5.2 & 51,045 & 1,314 & 1.34 \\
4 & 7.0 & 47,240 & 1,047 & 2.20 \\
\hline
\end{tabular}

Ethylene treated fruits were allowed to ripen at $25^{\circ} \mathrm{C}$ and high relative humidity. On day 0,2 and 4, 5-mm-thick slices were infiltrated with $\mathrm{L}-\left[\mathrm{U}-{ }^{14} \mathrm{C}\right]$ leucine. Incorporation is expressed as $\mathrm{dpm}$ of ${ }^{14} \mathrm{C}$-leucine incorporated per $\mathrm{mg}$ protein in the tissue. Uptake is expressed as $\mathrm{dpm}$ per $\mathrm{g}$ pulp tissue. RNase activity is expressed as units per $\mathrm{mg}$ protein.

* Figures are means of duplicate analyses. 
Polyclar AT (polyvinylpyrrolidone) to protect protein from binding to polyphenols during grinding and centrifugation, but observed very little effect on the extraction of either APase or RNase. Addition of 2-mercaptoethanol to the medium gave only a slight positive effect. Used in the grinding medium, Triton X-1C0 strongly facilitated the extraction of APase activity from the fraction precipitated by low speed cetrifugation (5). The rate of extraction increased with the increase in the concentration of Triton $\mathrm{X}-100$ to saturation at about $1 \%(\mathrm{v} / \mathrm{v})$. Our recent results show that Triton X-100 does not completely solubilize APase from cell wall fragments, however, and that a significant activity still remains bound after the treatment.

The climacteric phase of fruit ripening marks the transition from maturity to senescence. It is a period of enhanced metabolic activity which leads to the breakdown of cellular structures and the completion of senescence (11). The climacteric is caused by, or closely associated with, enhanced ethylene production in the tissue $(1,8,9)$. The banana is one of the fruits having a typical climacteric and its rise in respiration is known to be caused by endogenous ethylene (4). Whether or not the rate of protein synthesis is enhanced during the climacteric in the banana has been a subject of controversy (2, $3,13)$. Sacher (13) demonstrated that the incorporation of leucine or phenylanine into protein declined during the period from the preclimacteric phase to the climacteric peak. $\mathrm{He}$ also demonstrated that the increase in membrane permeability, as determined by free space, preceded the onset of the climacteric rise in respiration. On the other hand, Brady et al. (2) and Brady and $\mathrm{O}^{\prime}$ Connell (3) showed, following ethylene treatment, that the rate of incorporation of lysine or valine into protein increased in pulp tissue concurrently with an increase in the rate of respiration. They concluded that in banana pulp cells the response to ethylene treatment included an increase in the rates of turnover of many of the soluble proteins of the tissue. Our present results showed that during ethyleneenhanced ripening there was a gradual dec- line in the rate of leucine incorporation into protein of the pulp tissue, while there was a sharp increase in RNase and APase activities. De Leo and Sacher(5) and Sacher (15) showed for banana and for avocado that the development of APase activity was reduced in the presence of cycloheximide, which suggested that the increase in APase activity may have resulted from de novo synthesis of enzyme protein. These results indicate that although there is some inconsistency in the enhancement of the rate of protein synthesis in general, some particular enzymes relating to senescence are induced during the climacteric period.

The development of APase and RNase activity coincided closely with the climacteric rise and the subsequent senescence. De Leo and Sacher (5) found that APase from banana fruit hydrolyzed ATP, UTP, glucose-6-P and glucose-1-P as well as $p$-nitrophenylphosphate, a synthetic substrate. It has been demonstrated that RNase activity increases during the aging or senescence of plant tissues (6). Rhodes and Wooltorton (10) reported that RNase activity increased in the peel tissue of apple in parallel with the climacteric rise in respiration. RNase activity in excised discs of turnip root increased during aging and the application of exogenous ethylene accelerated the rise in RNase activity (16). The physiological role and the mechanism of induction of RNase and APase remain to be established in relation to fruit ripening and senescence.

\section{Acknowledgments}

We thank Dr. S. F. Yang and Mr. G. Von Abrams, University of California, Davis, for reading the manuscript.

\section{Literature Cited}

1. Biale, J. B. 1960. Respiration of fruits. pp. 536-592. In : W. Runland (ed.) Handbuch der Pflanzenphysiologie. Vol. 12, Part 2. Springer Verlag, Berlin.

2. BRady, C. J., J. K. PAlmer, P. B. H. O'CONNEll and R. M. SMILliE. 1970. An increase in protein synthesis during ripening of the banana fruit. Phytochemistry $9: 1037-1047$.

3. BRADY, C. J. and P. B. H. O'CONNELl. 1976. On the significance of increased protein 
synthesis in ripening banana fruits. Aust. J. Plant Physiol. 3:301-310.

4. BURG, S. P. and E. A. BURG. 1962. Role of ethylene in fruit ripening. Plant Physiol. $37: 179-189$.

5. DE LEO, P. and J. A. SACHER. 1970. Senescence. Association of synthesis of acid phosphatase with banana ripening. Plant Physiol. $46: 208-211$.

6. DE LEO, P. and J. A. SACHER. 1970. Control of ribonuclease and acid phosphatase by auxin and abscisic acid during senescence of Rhoeo leaf sections. Plant Physiol. 46 : 806-811.

7. LOWry, O. H., N. J. ROSEBrough, A. L. FARR and R. J. RANDALl. 1951. Protein measurement with the Folin phenol reagent. J. Biol. Chem. $193:$ 265-275.

8. MCGLASSON, W. B. 1970. The ethylene factor. pp. 415-519. In : A. C. Hulme (ed.) The Biochemistry of fruits and their produsts. Vol. 1, Academic Press, London and New York.

9. PRATT, H. K. and J. D. Goeshl. 1969. Physiological roles of ethylene in plants. Ann. Rev. Plant Physiol. 20 : 541-584.

10. RHODES, M. J.C. and L. S. C. WOOLTORTON. 1967. The repsiration climacteric in apple fruits. The action of hydrolytic enzymes in peel tissue during the climacteric period in fruit detached from the tree. Phytochemistry $6: 1-12$.

11. RHODES, M. J.C. 1970. The climacteric and ripening of fruits. pp. 521-533 In : A. C. Hulme (ed.) The biochemistry of fruits and their products. Vol.1. Academic Press, London and New York.

12. RHODES, M. J.C. 1980. The maturation and ripening of fruits. pp. 157-205. In : K. V. Thimann (ed.): Senescence in plants. CRC Press, Inc.

13. SACHER, J. A. 1966. Permeability characteristic and amino acid incorporation during senescence (ripening) of banan tissue. Plant Physiol. 41 : 701-708.

14. SACHER, J. A. 1973. Senescence and postharvest physiology. Ann. Rev. Plant Physiol. 24 : 197-224.

15. SACHER, J. A. 1975. Acid phosphatase deveiopment during ripening of avocado. Plant Physiol. 55 : 382-385.

16. SACHER, J. A., D. ENGSTROM and D. BROOMFIELD. 1979. Ethylene regulation of wound-induced ribonuclease in turnip root tissue. Planta $144:$ 413-418.

17. SAmson, J. A. 1980. Tropical Fruits. Longman, London and New York.

18. YAMAGATA, H., K. TANAKA and Z. KASAI. 1979. Isozymes of acid phosphatase in aleurone particles of rice grains and their interconversion. Agric. Biol. Chem. $43: 2059-2066$.

19. YoshIOKA, H., Y. UEDA and K. CHACHIN. 1980. Effect of high temperature $\left(40^{\circ} \mathrm{C}\right)$ on the change of acid-phosphatase activity during banana fruit ripening. Nippon Shokuhin Kogyo Gakkaishi 27 : 511-516.

20. YOSHIOKA, H., Y. UEDA and K. CHACHIN. 1980. Inhibition of banana fruit ripening and decrease of protein synthesis at high temperature $\left(40^{\circ} \mathrm{C}\right)$. Nippon Shokuhin Kogyo Gakkaishi $27: 610-615$.

21. YOUNG, R.E. 1965. Extraction of enzymes from tannin-bearing tissue. Arch. Biochem. Biophys. $111: 174-180$.

\section{バナナ果実追熟中の酸性ホスファターゼ㘧よびリボヌクレアーゼの活性増大}

兵藤 宏・田中邦明・鈴木利郎・水越雅之・田坂吉史

(静岡大学農学部)

\section{摘要}

酸性ホスファターゼ抢よびリボヌクレアーゼの活性は バナナ果実の果肉組織のクリマクテリック执よびその後 の老化と関連して著しく増大した．酸性ホスファターゼ の活性は $2,000 \mathrm{~g}$ の遠心分離により得られる上澄液, 沈 でん分画に拀いて共に增加した．追熟の初期では沈でん 分画に怙ける活性の方が上澄液のそれよりもかなり高か った。リボヌクレアーゼの場合は常に上澄液の活性がか なり高かった。ポリアクリルアミド電気泳動により酸性
ホスファターゼの 9 つの成分に分離された。上澄液と沈 でん，未熟果実と追熟果実の間でそれぞれアイソザイム には本質的な差異は認められなかった。 いくつかのアイ ソザイムは追熟過程で活性が増大した。 ${ }^{14} \mathrm{C}-$ ロインンの タンパク質へのとりこみは追熟の進行と共に徐々に減少 した。しかし ${ }^{14} \mathrm{C}-$ ロイシンの組織への吸収は追熟が進 むことにより增大した． 